\title{
Lymphocyte proliferative response in vitro and its cellular dependency in guinea-pigs with experimental allergic orchitis
}

\author{
K. Hojo, C. Hiramine and M. Ishitaki \\ Department of Pathology, Osaka City University Medical School, Osaka 545, Japan
}

\begin{abstract}
Summary. The development of cellular hypersensitivity was measured by the proliferative response of lymph node cells in vitro and a skin test to partly purified testicular antigen. There was a slight stimulation of lymph node cells and of the delayed cutaneous response at 1-2 weeks after sensitization with testicular antigen in Freund's complete adjuvant and then, after a decline in response, there was a pronounced peak at 6 weeks after sensitization. The early response coincided with the onset and active inflammatory stage of the effect on the testis, while the major peak was consistent with a state of aspermatogenesis.

The proliferative response of unseparated lymph node cells could not be attributed to the function of $\mathrm{T}$ or B cells acting alone, although at 6 weeks after sensitization B-cell populations did become slightly responsive to antigen. The response of $T$ lymphocytes was enhanced by the presence of $B$ lymphocytes or peritoneal macrophages at 2 and 6 weeks after sensitization, but B cells did not appear to interact with macrophages. We conclude that $T$ cells are essential to the proliferative response of lymph node cells during the induction of experimental allergic orchitis in guinea-pigs.
\end{abstract}

\section{Introduction}

Experimental allergic orchitis is an organ-specific autoimmune disease affecting not only the testis but also the epididymis and it has been induced in several species by the injection of crude or purified testis extracts in Freund's complete adjuvant. There is, however, controversy of whether the tissue damage is caused by humoral antibodies or by cellular hypersensitivity. A study of local adoptive transfer with peritoneal exudate cells enriched with or depleted of $T$ lymphocytes showed that induction of mononuclear invasive testicular lesions was $\mathrm{T}$ celldependent (Tung, Leong \& McCarty, 1977). The concomitant demonstration of the failure to develop experimental allergic orchitis in hypothymic nu/nu mice, despite adequate orchitogenic challenge, and the complete restoration of the capacity to develop orchitis by reconstitution of $\mathrm{nu} / \mathrm{nu}$ mice with syngeneic thymocytes has provided further evidence for the requirement of $\mathrm{T}$ lymphocytes for induction of experimental allergic orchitis (Bernard, Mitchell, Leydon \& Bargerbos, 1978). Nevertheless, antisera to spermatozoa have been shown to affect the testis and epididymis (Tung, Unanue \& Dixon, 1971; Toullet \& Voisin, 1976). In spite of the strong evidence in favour of the participation of cellular hypersensitivity in the pathogenesis of experimental allergic orchitis, there is little information concerning the in-vitro lymphocyte response to stimulation with testicular antigen. Mazzolli (1971) has reported inhibition of macrophage 
migration and Muir \& Turk (1979) have studied the lymphocyte transformation of peripheral blood leucocytes.

The present experiments investigated the proliferative response of lymph node cells in vitro to homologous testicular antigen in guinea-pigs.

\section{Materials and Methods}

Male Hartley guinea-pigs (outbred) weighing 450-600 g were purchased from Shizuoka Animal Laboratory, Shizuoka Prefecture, Japan.

Antigens. Homologous testicular antigen was prepared according to the fractionation procedure of sperm glycoproteins described by Hagopian, Jackson, Carlo, Limjuco \& Eylar (1975); the Step 5 fraction was used for both immunization and lymphocyte stimulation in vitro. Testes and epididymides were frozen immediately after slaughter and when required were homogenized in chloroform-methanol $(2: 1, \mathrm{v} / \mathrm{v})$ at $20^{\circ} \mathrm{C}$. After standing for $3 \mathrm{~h}$ at $4{ }^{\circ} \mathrm{C}$ the aqueous phase was extracted in acetone and air-dried. The delipidated tissue powder was stirred overnight in distilled water adjusted to $\mathrm{pH} 3.0$ by dropwise addition of $12 \mathrm{~N}-\mathrm{HCl}$. The filtrate from the acid extraction process (Step 3 of the original method) was neutralized to $\mathrm{pH} 6.0$ with concentrated ammonium hydroxide and precipitated by addition of solid ammonium sulphate to $85 \%$ saturation. The precipitate was dissolved and dialysed extensively to remove ammonium sulphate completely. The acid extract of the testes had high orchitogenic and aspermatogenic activity, and was referred to as testicular antigen. The protein concentration was calculated by the method of Lowry, Rosebrough, Farr \& Randall (1951); about $760 \mathrm{mg}$ protein was obtained from the ammonium precipitate of $180 \mathrm{~g}$ frozen testicular tissue.

Immunization. An emulsion was prepared from equal parts of Freund's complete adjuvant (Difco, Detroit, Michigan; containing $1 \mathrm{mg}$ killed Mycobacterium tuberculosis $/ \mathrm{ml}$ ) and a solution of testicular antigen in $0.9 \%(\mathrm{w} / \mathrm{v}) \mathrm{NaCl}$ such that there was $500 \mu \mathrm{g}$ testicular antigen protein in $0.3 \mathrm{ml}$ of the emulsion. Guinea-pigs were immunized by footpad and nuchal injection with a single dose of $0.3 \mathrm{ml}$ of the emulsion and 4-6 were killed at 1, 2, 3, 4, 6 and 8 weeks after immunization. Controls were similarly injected with an emulsion of saline and Freund's complete adjuvant.

Skin testing. Before being killed, each animal was tested once by an intradermal flank injection of testicular antigen $(100 \mu \mathrm{g}$ protein $/ 0.1 \mathrm{ml}$ saline). The diameter and the thickness of induration were measured at 6,24 and $48 \mathrm{~h}$ after injection and then animals were killed.

Media. All washing procedures were performed in Hanks' balanced salt solution. For cell preparation, Eagle's minimum essential medium (MEM) with $10 \%$ heat-inactivated fetal calf serum (FCS; GIBCO, Grand Island, New York), 100 units penicillin/ml and $100 \mu \mathrm{g}$ streptomycin/ml (MEM-FCS) was used. The temporal sequence of lymphocyte proliferative response after immunization was studied with cells cultured in medium MEM-FCS, while the cellular interactions occurring in this response used cell cultures with medium RPMI 1640 (GIBCO) supplemented with $10 \%$ FCS, penicillin and streptomycin (RPMI-FCS).

Cell collection and preparation. Lymph node cells were obtained from the draining and remote lymph nodes of a sensitized animal. The nodes were excised and teased with forceps into cold Hanks' balanced salt solution. The cells were washed, passed through a stainless-steel mesh, and applied to a column of glass-beads which was then incubated for $1 \mathrm{~h}$ at $37^{\circ} \mathrm{C}$ in $5 \%$ $\mathrm{CO}_{2}$. Cells which did not adhere to the glass beads were separated into fractions enriched with $\mathrm{T}$ or B lymphocytes by a slight modification of the method of Lipsky \& Rosenthal (1976). A T lymphocyte-enriched population was prepared by passing lymph node cells over a double nylonwool column: a $20 \mathrm{ml}$ syringe packed with $1.5 \mathrm{~g}$ sterilized nylon wool (Wako Pure Chemicals, Osaka). Of the cells eluted from the second passage, $>94 \%$ formed rosettes with rabbit erythrocytes, while $<2 \%$ had a receptor for $\mathrm{C} 3$ as assessed by rosette formation by sheep 
erythrocytes coated with antibody and complement. A B lymphocyte-enriched population was prepared by mechanically dislodging the adherent cells from the first-column nylon after removal of loosely adherent cells by rapidly pouring warm medium through the column. The contaminating $\mathrm{T}$ lymphocytes were removed by rosette formation of erythrocytes and sedimentation with sodium metrizoate-Ficoll (Nyegaard, Oslo) cushions. The resultant population was enriched in B lymphocytes, with $>90 \%(93-95 \%)$ possessing a C3 receptor, whereas $<2 \%$ formed rosettes with rabbit erythrocytes. The number of macrophages present in the T- and Brich populations was less than $1 \%$ and $2 \%$, respectively. Both T- and B-cell populations were $>96 \%$ viable as estimated by trypan blue dye exclusion.

Peritoneal exudate cells were obtained from a sensitized guinea-pig 4 days after intraperitoneal inoculation of $10 \mathrm{ml}$ Bayol F (Esso, Texas). Peritoneal exudate cells suspended in MEM-FCS were plated on glass Petri dishes and incubated at $37^{\circ} \mathrm{C}$ in $5 \% \mathrm{CO}_{2}$. At 4,6 and 12 $\mathrm{h}$ after incubation, non-adherent cells were washed away and then the adherent cells were dislodged from the plates with a rubber policeman. The resultant cell population was highly enriched in macrophages ( $>98 \%$ as determined by morphology and latex particle uptake). Each cell population (unseparated, $\mathrm{T}$ and $\mathrm{B}$ lymphocytes, and macrophages) was suspended in RPMIFCS and used for cell cultures.

Mitomycin C treatment. Macrophages and T and B lymphocyte populations in RPMI-FCS medium were exposed to mitomycin C (20 $\mu \mathrm{g} / \mathrm{ml}$ : Sigma Chemical Co., St Louis, Missouri) for $30 \mathrm{~min}$ at $37^{\circ} \mathrm{C}$ and washed 3 times with excess medium.

Assay of antigen-induced lymphocyte proliferation. Each cell suspension at a concentration of 1-2 $\times 10^{6} \mathrm{cell} / \mathrm{s} / \mathrm{ml}$ was divided into $1 \mathrm{ml}$ aliquots, and culture tubes were incubated with or without antigen at $37^{\circ} \mathrm{C}$ for 4 days in $5 \% \mathrm{CO}_{2}$. At $24 \mathrm{~h}$ before the end of culture $1 \mu \mathrm{Ci}\left[{ }^{3} \mathrm{H}\right.$ ]thymidine (sp. act. 5.0 Ci/mmol: Radiochemical Centre, Amersham, U.K.) was added to each culture and incorporation of $\left[{ }^{3} \mathrm{H}\right]$ thymidine into acid-insoluble material was counted. The ratio of c.p.m. with antigen to c.p.m. without antigen was considered to be the stimulation index. Each experimental point was set up in triplicate. The significance of differences between means was determined by Student's $t$ test.

Histological studies. The testes and epididymides of each autopsied guinea-pig were examined by light microscopy after fixation in $10 \%$ phosphate-buffered formalin and embedding in paraffin wax. Sections were stained with haematoxylin and eosin.

\section{Results}

\section{Histological changes}

The testicular antigen used in this study showed great orchitogenic and aspermatogenic activity. The principal histological changes consisted of epididymitis, orchitis and aspermatogenesis, and were generally similar to those previously described (Waksman, 1959; Tung, Unanue \& Dixon, 1970). At 7 days after sensitization the testis and epididymis were almost normal, but there was some eosinophilic fluid and a few inflammatory cells (monocytes and polymorphonuclear leucocytes) around the walls of small veins amongst seminiferous tubules. At 2 weeks after sensitization, affected areas of the testis showed perivascular infiltration of mononuclear cells (monocytes and lymphocytes) interspersed with scattered polymorphs in the intertubular spaces and direct invasion of the tubules by these cells (Pl. 1, Fig. 1). In the most severe lesions, the affected areas presented not only diffuse inter- and intra-tubular infiltrates predominantly consisting of monocytes and polymorphonuclear leucocytes, but also necrotic vessels with fibrin precipitates within the lumen, accompanied by parenchymal coagulation necrosis (Pl. 1, Fig. 2). In the efferent ducts there were lesions characterized by a suppurative inflammation. The epididymis contained a mixture of spermatozoa, polymorphonuclear 
leucocytes and, to a lesser extent, monocytes, which eventually became a pseudoabscess and/or a true abscess (Pl. 1, Figs 3 and 4). At 3 weeks, the inflammatory infiltrates in the testis were noticeably lessened and in places took on a focal granulomatous appearance. The seminiferous tubules were aspermatogenic. In most animals, the suppurative lesions in the epididymis began to decline. At 4 weeks, the seminiferous tubules were atrophic and almost completely empty of germinal cells, and the intertubular infiltrations were replaced either by fibroblastic proliferations or oedematous acellular stroma. In contrast, there was proliferation and vacuolation of Sertoli cells and hypertrophy of Leydig cell masses. The suppurative lesions of the epididymis had subsided almost completely at this stage. At 6 weeks, the testis as a whole showed marked diminution in size; there was marked atrophy or disappearance of Sertoli cells as well as complete aspermatogenesis (Pl. 2, Figs 5-8). At 8 weeks, the main histological appearance was of aspermatogenic tubules with a few scattered lymphocytes in the interstitium, but there were a few tubules containing a small number of spermatids and spermatogonia or spermatocytes, suggesting the beginning of regeneration of the germinal epithelium.

\section{Stimulation of $\left[{ }^{3} \mathrm{H}\right]$ thymidine incorporation in vitro}

To establish an appropriate dosage level of testicular antigen at which lymph node cell proliferation is induced, cell cultures were incubated with various concentrations of testicular

\section{PLATE 1}

Histological sections of representative lesions of testes and epididymides taken from guinea-pigs 2 weeks after sensitization with testicular antigen in Freund's complete adjuvant.

Fig. 1. Section of testis showing massive interstitial inflammation. Infiltrating cells, mainly monocytes and lymphocytes, are present in the interstitium and in clusters within the lumen of the seminiferous tubules. The heavy peritubular infiltrates (arrows) extend across the boundary tissue into the basal portion of the germinal epithelium. Early destruction and slight hypospermatogenesis of the germinal epithelium is apparent. $\times 230$.

Fig.2. Section of the most severely affected testis. Heavy interstitial infiltrates, predominantly of polymorphonuclear leucocytes and monocytes accompany a fibrinous exudate which precipitates within the lumen and the wall of the small vein (V), extending outward into the stroma (arrow). As a result of this, there is partial disruption of the wall of the seminiferous tubule (arrow head) as well as coagulation (ischaemic) necrosis of the germinal epithelium. $\mathbf{S}=$ seminiferous tubules. $\times 230$.

Fig. 3. Section of the cauda epididymidis. The epididymal ducts are filled with a mixture of spermatozoa, polymorphonuclear leucocytes and macrophages, indicating a true abscess. $\times 46$. Inset: $\times 230$.

Fig. 4. Higher magnification of part of Fig. 3. The inflammatory interstitial lesion is adjacent to the epididymal duct (E). There is a polymorphonuclear leucocyte-rich exudate showing a granulomatous response characterized by proliferation of newly formed capillaries and fibroblasts with scattered lymphocytes. The epithelium of the duct is entirely desquamated. $\times 230$.

\section{PLATE 2}

Histological sections of representative lesions of testes taken from guinea-pigs 6 weeks after sensitization with testicular antigen in Freund's complete adjuvant.

Figs 5 and 6. Sections showing complete aspermatogenesis. The intertubular spaces are variably thickened by hyperplastic Leydig cells, together with fibroblasts and a few small lymphocytes. The Sertoli cells are grossly vacuolated and apparently disrupted. Fig. 5, ×60; Fig. 6, ×230.

Figs 7 and 8. Sections showing complete aspermatogenesis. The intertubular spaces are not thickened by hyperplastic Leydig cells and there are no active signs of inflammation. The atrophic seminiferous tubules show vacuolation disintegration and disappearance of the Sertoli cells. Fig. 7, $\times 46 ;$ Fig. 8, $\times 170$. 


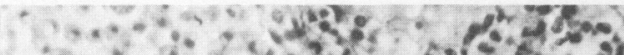

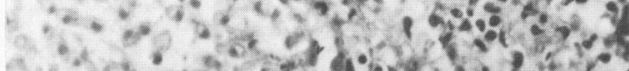

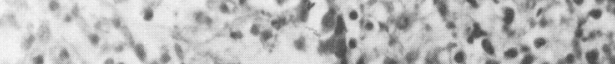

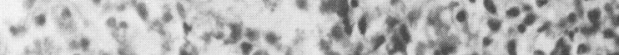

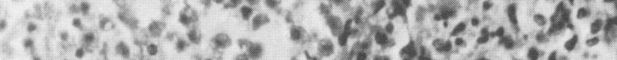

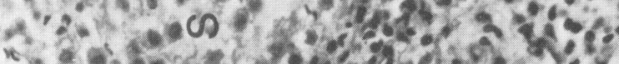

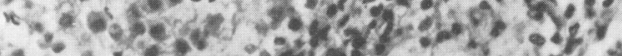

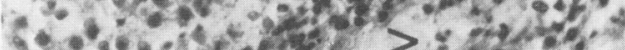

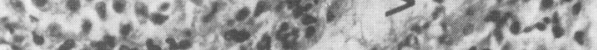

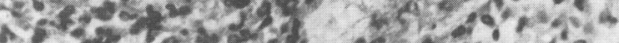

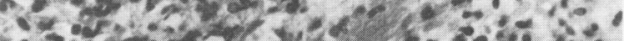

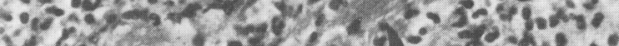

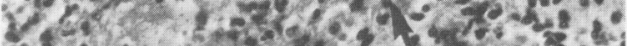

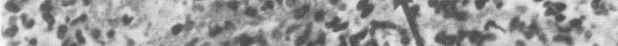

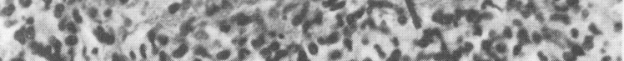

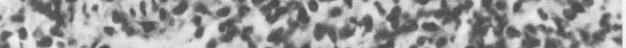

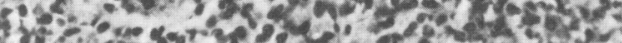

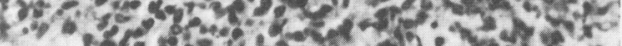

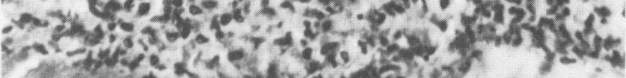
+20 the

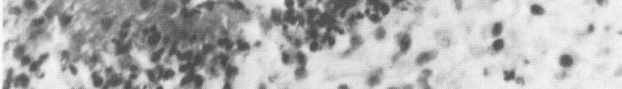

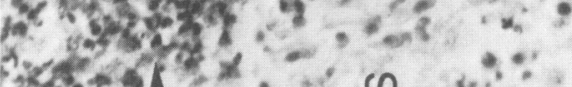

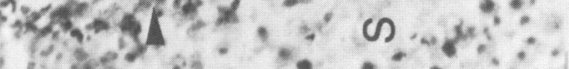

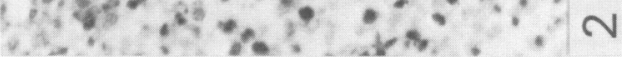

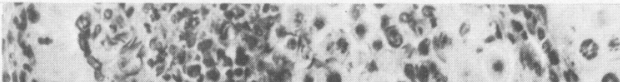

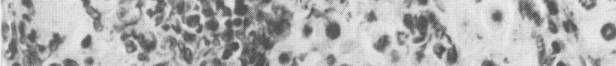

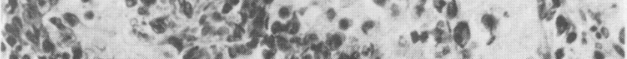

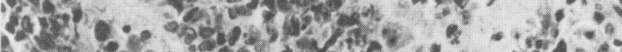

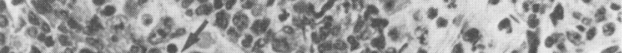
6.t.

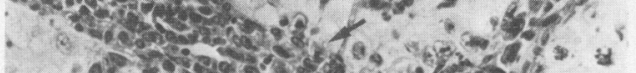

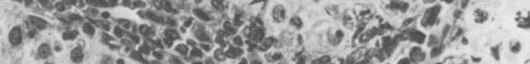

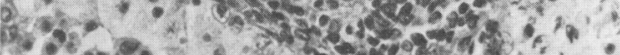

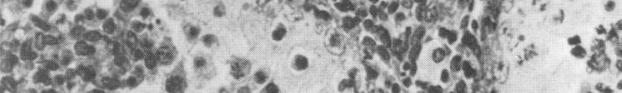

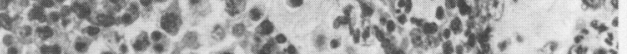

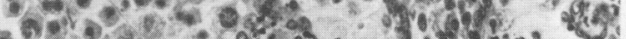

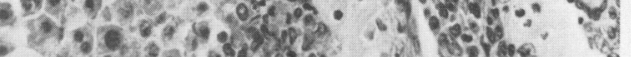

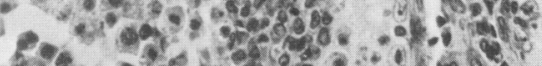

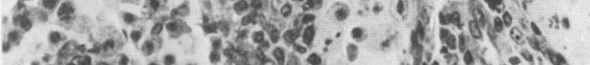

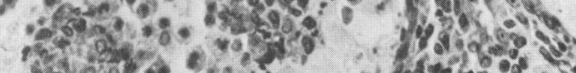

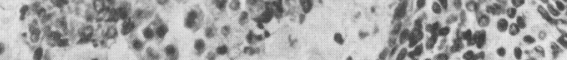
1.

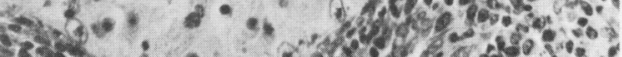

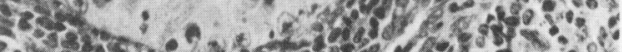

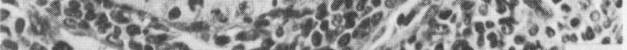

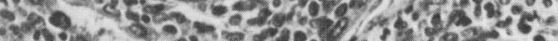

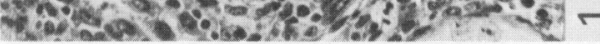

ice

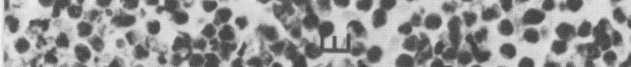

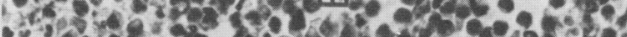
-

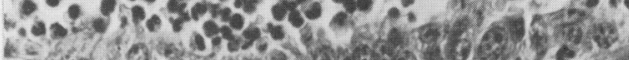

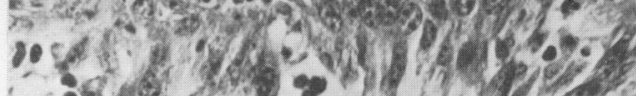
i. 80.25 .

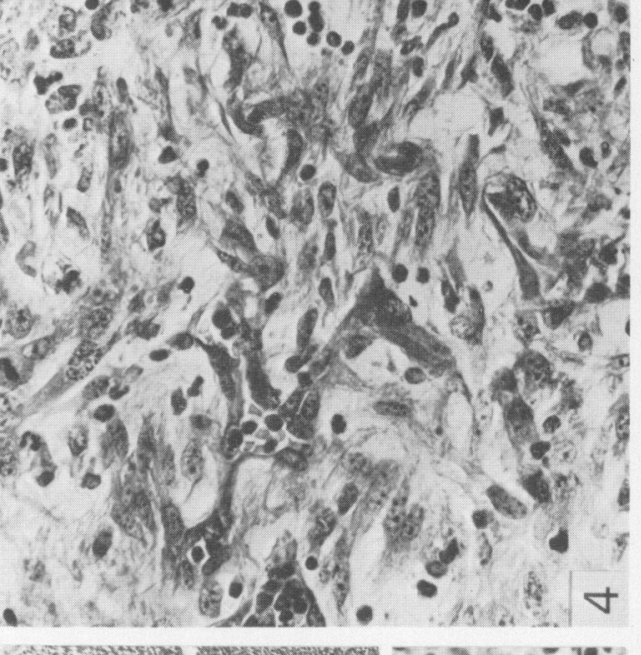

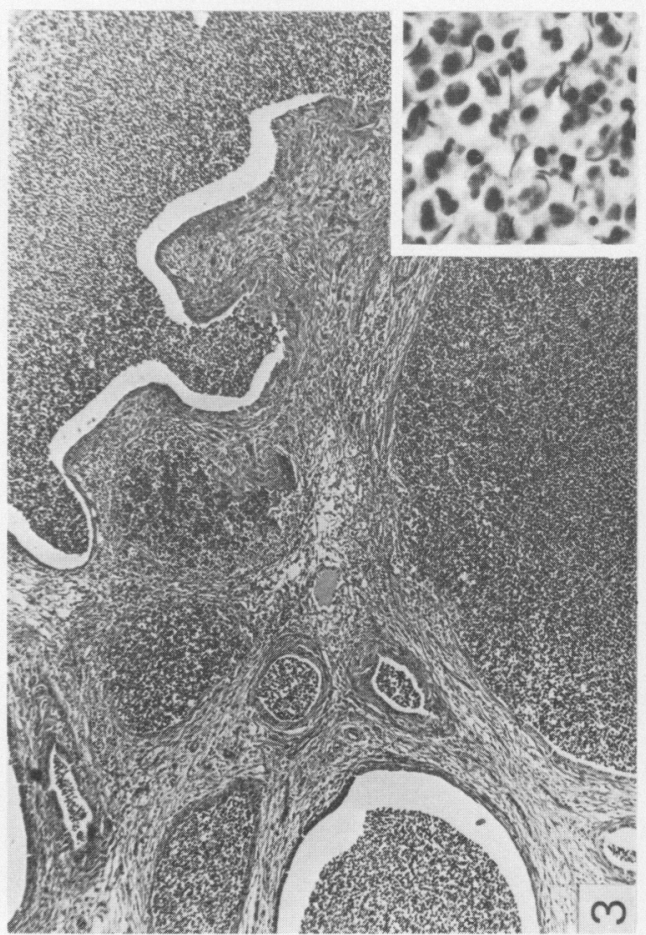




\section{PLATE 2}
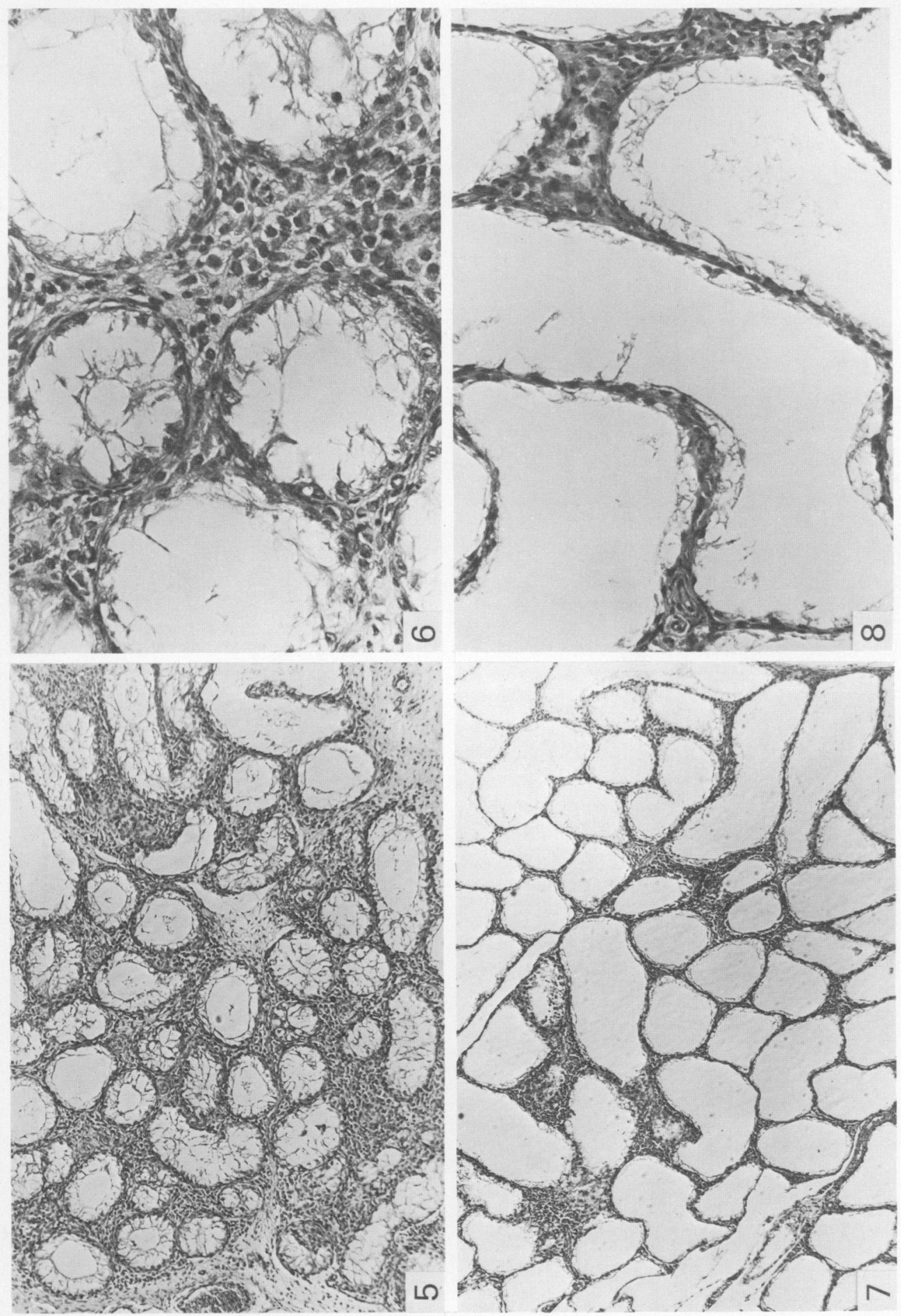
Table 1. Effect of various concentrations of testicular antigen on the proliferative response in vitro (measured by the stimulation index (see text) for 2-3 experiments) of lymph node cells obtained from guinea-pigs sensitized with testicular antigen in Freund's complete adjuvant (FCA)

\begin{tabular}{lcccccc}
\hline & \multicolumn{6}{c}{ Testicular antigen conc. $(\mu \mathrm{g}$ protein $/ \mathrm{ml})$} \\
\cline { 2 - 7 } \multicolumn{1}{c}{ Treatment } & 1 & 10 & 100 & 200 & 500 & 1000 \\
\hline None (control) & 0.96 & 0.99 & 1.00 & 0.96 & 1.14 & 1.26 \\
Testicular antigen & & & & & & \\
$\quad$ 2 weeks & 1.00 & 1.17 & 2.48 & 2.31 & 2.43 & 2.53 \\
$\quad$ 4 weeks & 1.15 & 1.86 & 2.28 & 2.55 & 2.50 & - \\
$\quad$ 8 weeks & 1.29 & 2.50 & 3.55 & 3.44 & 2.75 & 2.69 \\
FCA alone (control) & & & & & & \\
3 weeks & 0.90 & 0.89 & 1.33 & 1.36 & 1.52 & 1.18 \\
7 weeks & 1.00 & 1.00 & 1.35 & 1.40 & 1.78 & - \\
\hline
\end{tabular}

antigen (1-1000 $\mu \mathrm{g}$ protein $/ \mathrm{ml}$ ). As shown in Table 1, a stimulation index of $>2$ was provoked by testicular antigen concentrations of $>100 \mu \mathrm{g}$ protein $/ \mathrm{ml}$ at 2 or 4 weeks and $>10 \mu \mathrm{g}$ protein $/ \mathrm{ml}$ at 8 weeks after sensitization. There was some stimulation $(P<0.05)$ in response to Freund's complete adjuvant at a concentration of $500 \mu \mathrm{g}$ protein $/ \mathrm{ml}$, and so a dose of $100 \mu \mathrm{g}$ testicular antigen protein $/ \mathrm{ml}$ was chosen for subsequent study.

\section{Lymphocyte proliferative response to testicular antigen}

There was a small increase in response by Weeks 1 and 2 after sensitization (Table 2), i.e. when the first sign of orchitis was detectable. After a fall at Week 3 values increased again to reach a peak at 6 weeks. Values were again decreasing by 8 weeks when the experiment was terminated. Control cultures with cells from animals injected with Freund's complete adjuvant

Table 2. The lymphocyte proliferative response in vitro to testicular antigen (TA) in cultures of lymph node cells obtained from guinea-pigs at weekly intervals after sensitization with TA in Freund's complete adjuvant

(FCA)

\begin{tabular}{lccc}
\hline \multirow{2}{*}{$\begin{array}{c}\text { Weeks after } \\
\text { sensitization }\end{array}$} & Without TA & With TA & Stimulation index \\
\cline { 2 - 4 } & $82 \pm 2$ & $84 \pm 1$ & $1.00 \pm 0 \cdot 05$ \\
0 (control) & $186 \pm 64$ & $436 \pm 171$ & $2 \cdot 34 \pm 0 \cdot 51$ \\
1 & $549 \pm 265$ & $1165 \pm 410$ & $2 \cdot 20 \pm 0.46$ \\
2 & $1398 \pm 500$ & $1951 \pm 697$ & $1.40 \pm 0 \cdot 09 *$ \\
3 & $245 \pm 90$ & $471 \pm 131$ & $2 \cdot 16 \pm 0.51 \dagger$ \\
4 & $618 \pm 244$ & $4181 \pm 1217$ & $7.27 \pm 2 \cdot 37 \ddagger$ \\
6 & $531 \pm 95$ & $1863 \pm 210$ & $3.55 \pm 0.24 \S$ \\
8 & & & \\
FCA alone (control) & $506 \pm 105$ & $443 \pm 76$ & $0.83 \pm 0.07$ \\
2 & $1163 \pm 313$ & $1457 \pm 214$ & $1 \cdot 33 \pm 0.11$ \\
3 & $256 \pm 102$ & $343 \pm 126$ & $1 \cdot 35 \pm 0.05$ \\
7 & &
\end{tabular}

Values are mean \pm s.d. of 4-6 animals in each group.

- Significantly lower than value at 2 weeks, $P<0.05$.

$\dagger$ Significantly higher than value at 3 weeks, $P<0.05$.

$\ddagger$ Significantly higher than values at 1 and 2 weeks, $P<0.02$.

§ Significantly lower than value at 6 weeks, $P<0.05$. 
Table 3. Delayed skin reaction to testicular antigen in guinea-pigs at weekly intervals after sensitization with testicular antigen in Freund's complete adjuvant

\begin{tabular}{lcc}
\hline & \multicolumn{2}{c}{ Skin reaction at $24 \mathrm{~h}$} \\
\cline { 2 - 3 } $\begin{array}{c}\text { Weeks after } \\
\text { sensitization }\end{array}$ & $\begin{array}{c}\text { Mean diam. } \\
\text { of erythema (mm) }\end{array}$ & $\begin{array}{c}\text { Increase in double } \\
\text { thickness (mm) }\end{array}$ \\
\hline 0 (control & $3.5 \pm 1.4$ & $0.5 \pm 0.3$ \\
1 & $22.1 \pm 2.5$ & $2.1 \pm 0.6$ \\
2 & $21.8 \pm 3.8$ & $2.1 \pm 0.6$ \\
3 & $16.3 \pm 5.1$ & $1.7 \pm 0.9$ \\
4 & $17.4 \pm 2.7$ & $1.8 \pm 0.7$ \\
6 & $29.6 \pm 2.8$ & $2.6 \pm 0.6$ \\
8 & $18.8 \pm 4.0$ & $2.3 \pm 1.0$ \\
\hline
\end{tabular}

Values are mean \pm s.d. of 4-6 experiments.

alone showed little change in responsiveness. When the lymphocyte proliferative response to testicular antigen was expressed as the mean c.p.m. of $\left[{ }^{3} \mathbf{H}\right]$ thymidine incorporation, the early increased response at Weeks 1-2 was altered to Weeks 2-3 because there was an increased $\left[{ }^{3} \mathrm{H}\right]$ thymidine incorporation in cultures without testicular antigen at $2(P<0.05)$ and 3 weeks $(P<0.005)$. A similar increment of spontaneous $\left[{ }^{3} \mathrm{H}\right]$ thymidine incorporation was observed at

Table 4. Effects of supplemental autologous mitomycin C-treated macrophages and B lymphocytes on the testicular antigen (TA)-induced proliferative response of lymph node T-cell populations obtained from TA-sensitized guinea-pigs

\begin{tabular}{|c|c|c|c|c|c|}
\hline \multirow{3}{*}{$\begin{array}{c}\text { Cell } \\
\text { population }\end{array}$} & \multirow{3}{*}{$\begin{array}{c}\text { TA } \\
(\mu \mathrm{g} \text { protein } / \mathrm{ml})\end{array}$} & \multicolumn{4}{|c|}{$\left[{ }^{3} \mathrm{H}\right]$ Thymidine incorporation (c.p.m.) } \\
\hline & & \multicolumn{2}{|c|}{2 weeks } & \multicolumn{2}{|c|}{6 weeks } \\
\hline & & Exp. 1 & Exp. 2 & Exp. 3 & Exp. 4 \\
\hline $\begin{array}{l}\text { Unseparated } \\
\text { cells }\end{array}$ & $\begin{array}{r}0 \\
100\end{array}$ & $\begin{array}{r}673 \pm 167 \\
1453 \pm 312\end{array}$ & $\begin{array}{l}1693 \pm 44 \\
6029 \pm 922\end{array}$ & $\begin{array}{r}88 \pm 14 \\
251 \pm 24\end{array}$ & $\begin{array}{c}264 \pm 17 \\
2640 \pm 389\end{array}$ \\
\hline $\begin{array}{l}\mathrm{T} \text { cells } \\
\text { alone }\end{array}$ & $\begin{array}{r}0 \\
100 \\
\end{array}$ & $\begin{array}{l}38 \pm 5 \\
35 \pm 8 \\
\end{array}$ & $\begin{array}{l}50 \pm 8 \\
56 \pm 14\end{array}$ & $\begin{array}{l}40 \pm 3 \\
52 \pm 2\end{array}$ & $\begin{array}{c}54 \pm 2 \\
105 \pm 11\end{array}$ \\
\hline $\begin{array}{c}\mathrm{T}+\text { macrophages } \\
1: 0 \cdot 1\end{array}$ & $\begin{array}{r}0 \\
100\end{array}$ & $\begin{array}{l}196 \pm 35 \\
665 \pm 181\end{array}$ & - & $\begin{array}{l}36 \pm 15 \\
60 \pm 8\end{array}$ & $\begin{array}{l}104 \pm 16 \\
385 \pm 31\end{array}$ \\
\hline $1: 0 \cdot 5$ & $\begin{array}{r}0 \\
100\end{array}$ & $\begin{array}{c}273 \pm 74 \\
1412 \pm 240^{*}\end{array}$ & $\begin{array}{l}145 \pm 17 \\
480 \pm 139 \dagger\end{array}$ & $\begin{array}{c}67 \pm 7 \\
451 \pm 58 \ddagger\end{array}$ & $\begin{array}{c}366 \pm 28 \\
4849 \pm 674 \ddagger\end{array}$ \\
\hline $1: 1$ & $\begin{array}{r}0 \\
100 \\
\end{array}$ & $\begin{array}{c}329 \pm 39 \\
2439 \pm 159 \\
\end{array}$ & $\begin{array}{l}215 \pm 38 \\
753 \pm 178\end{array}$ & $\begin{array}{l}145 \pm 17 \\
608 \pm 80 \\
\end{array}$ & $\begin{array}{r}683 \pm 260 \\
4578 \pm 495 \\
\end{array}$ \\
\hline $\begin{array}{c}T+B \text { cells } \\
1: 0 \cdot 5\end{array}$ & $\begin{array}{r}0 \\
100\end{array}$ & $\begin{array}{c}52 \pm 11 \\
645 \pm 157 \S\end{array}$ & $\begin{array}{c}75 \pm 10 \\
448 \pm 105 \S\end{array}$ & $\begin{array}{c}27 \pm 4 \\
481 \pm 176 \dagger\end{array}$ & $\begin{array}{l}164 \pm 38 \\
574 \pm 1229\end{array}$ \\
\hline $1: 1$ & $\begin{array}{r}0 \\
100 \\
\end{array}$ & $\begin{array}{c}109 \pm 10 \\
1286 \pm 114\end{array}$ & $\begin{array}{c}171 \pm 45 \\
1701 \pm 128 \\
\end{array}$ & $\begin{array}{c}25 \pm 3 \\
127 \pm 28\end{array}$ & $\begin{array}{l}218 \pm 35 \\
719 \pm 153\end{array}$ \\
\hline Macrophages & $\begin{array}{r}0 \\
100\end{array}$ & $\begin{array}{l}85 \pm 15 \\
54 \pm 9\end{array}$ & $\begin{array}{l}53 \pm 5 \\
54 \pm 9\end{array}$ & $\begin{array}{l}52 \pm 11 \\
52 \pm 8\end{array}$ & $\begin{array}{l}73 \pm 8 \\
79 \pm 11\end{array}$ \\
\hline B cells & $\begin{array}{r}0 \\
100\end{array}$ & $\begin{array}{l}93 \pm 5 \\
90 \pm 6\end{array}$ & $\begin{array}{l}85 \pm 5 \\
88 \pm 3\end{array}$ & $\begin{array}{l}83 \pm 5 \\
76 \pm 10\end{array}$ & $\begin{array}{l}80 \pm 6 \\
82 \pm 4\end{array}$ \\
\hline
\end{tabular}

Each value represents the mean \pm s.d. of a triplicate culture in a single experiment.

Significantly different from corresponding value without TA, ${ }^{*} P<0.005 ; \dagger P<0.05 ; \ddagger P<0.001$; $\S P<0.01 ;$ 甲 $P<0.02$. 
2 and 3 weeks $(P<0.001)$ for cells from the control animals. The stimulation index peak at 6 weeks after sensitization was still apparent when expressed as c.p.m.

\section{Changes in skin response}

As shown in Table 3 , the delayed skin reactivity to testicular antigen after sensitization followed a pattern similar to that described above. The response was well established at Week 1 , reduced at Weeks 3-4 and maximal at 6 weeks. Untreated or Freund's complete adjuvantinjected control animals displayed only small erythema, $<5 \mathrm{~mm}$ in diameter, against testicular antigen.

\section{Cellular interactions}

Purified populations of $\mathrm{T}$ and $\mathrm{B}$ lymph-node lymphocytes and autologous peritoneal macrophages were used from guinea pigs at 2 and 6 weeks after testis sensitization. To estimate an appropriate number of accessory cells for addition to cultures of purified lymphocytes, various numbers of mitomycin C-treated supplemental cells (autologous) were added to $1 \times 10^{6} \mathrm{~T}$ or B lymphocytes taken from animals with orchitis. In Table 4 the proliferation of $\mathrm{T}$ lymphocytes is shown as a function of the number of supplemental mitomycin C-treated autologous macrophages or B lymphocytes added. The response of the $T$ lymphocytes was adequately potentiated by the addition of other cells at a T lymphocytes : macrophages or B lymphocytes ratio of $1: 0 \cdot 5$. Similar experiments (Table 5) showed that the response of B lymphocytes was either not enhanced or decreased by the addition of mitomycin C-treated macrophages $(1: 0.5$ or $1: 1$

Table 5. Effects of supplemental autologous mitomycin C-treated macrophages and $T$ lymphocytes on the testicular antigen (TA)-induced proliferative response of lymph node B-cell populations obtained from TA-sensitized guinea pigs

\begin{tabular}{|c|c|c|c|c|c|}
\hline \multirow{3}{*}{$\begin{array}{c}\text { Cell } \\
\text { population }\end{array}$} & \multirow{3}{*}{$\begin{array}{c}\text { TA } \\
(\mu \mathrm{g} \text { protein } / \mathrm{ml})\end{array}$} & \multicolumn{4}{|c|}{$\left[{ }^{3} \mathrm{H}\right]$ Thymidine incorporation (c.p.m.) } \\
\hline & & \multicolumn{2}{|c|}{2 weeks } & \multicolumn{2}{|c|}{6 weeks } \\
\hline & & Exp. 1 & Exp. 2 & Exp. 3 & Exp. 4 \\
\hline Unseparated cells & $\begin{array}{r}0 \\
100\end{array}$ & $\begin{array}{l}2118 \pm 352 \\
5062 \pm 1126\end{array}$ & $\begin{array}{r}673 \pm 167 \\
1453 \pm 312\end{array}$ & $\begin{array}{c}264 \pm 17 \\
2640 \pm 389\end{array}$ & $\begin{array}{l}166 \pm 21 \\
501 \pm 45\end{array}$ \\
\hline B cells & $\begin{array}{r}0 \\
100\end{array}$ & $\begin{array}{l}868 \pm 78 \\
689 \pm 196\end{array}$ & $\begin{array}{c}783 \pm 73 \\
1069 \pm 234\end{array}$ & $\begin{array}{l}376 \pm 47 \\
526 \pm 139\end{array}$ & $\begin{array}{l}220 \pm 53 \\
572 \pm 42\end{array}$ \\
\hline $\begin{array}{l}\text { B + macrophages } \\
1: 0 \cdot 5\end{array}$ & $\begin{array}{r}0 \\
100\end{array}$ & $\begin{array}{l}839 \pm 106 \\
374 \pm 49\end{array}$ & $\begin{array}{l}858 \pm 53 \\
956 \pm 166\end{array}$ & $\begin{array}{l}454 \pm 18 \\
545 \pm 80\end{array}$ & $\begin{array}{c}524 \pm 114 \\
1205 \pm 64\end{array}$ \\
\hline $1: 1$ & $\begin{array}{r}0 \\
100 \\
\end{array}$ & $\begin{array}{l}544 \pm 52 \\
294 \pm 69 \\
\end{array}$ & $\begin{array}{l}1523 \pm 121 \\
1632 \pm 115 \\
\end{array}$ & $\begin{array}{l}539 \pm 133 \\
701 \pm 101 \\
\end{array}$ & $\begin{array}{r}689 \pm 74 \\
1089 \pm 98 \\
\end{array}$ \\
\hline $\begin{array}{c}\text { B + T cells } \\
1: 0.5\end{array}$ & $\begin{array}{r}0 \\
100\end{array}$ & $\begin{array}{c}640 \pm 66 \\
1162 \pm 124^{*}\end{array}$ & $\begin{array}{l}1051 \pm 132 \\
1562 \pm 176 \dagger\end{array}$ & $\begin{array}{c}468 \pm 90 \\
1248 \pm 127 \ddagger\end{array}$ & $\begin{array}{c}568 \pm 63 \\
1634 \pm 176 \ddagger\end{array}$ \\
\hline $1: 1$ & $\begin{array}{r}0 \\
100 \\
\end{array}$ & - & - & $\begin{array}{c}351 \pm 42 \\
1571 \pm 153 \\
\end{array}$ & $\begin{array}{c}512 \pm 49 \\
1271 \pm 120 \\
\end{array}$ \\
\hline Macrophages & $\begin{array}{r}0 \\
100\end{array}$ & $\begin{array}{l}74 \pm 11 \\
72 \pm 8\end{array}$ & $\begin{array}{l}85 \pm 15 \\
54 \pm 9\end{array}$ & $\begin{array}{l}92 \pm 8 \\
88 \pm 11\end{array}$ & $\begin{array}{l}85 \pm 9 \\
82 \pm 12\end{array}$ \\
\hline $\mathrm{T}$ cells & $\begin{array}{r}0 \\
100\end{array}$ & $\begin{array}{l}28 \pm 7 \\
19 \pm 11\end{array}$ & $\begin{array}{l}23 \pm 5 \\
24 \pm 4\end{array}$ & $\begin{array}{l}43 \pm 12 \\
45 \pm 9\end{array}$ & $\begin{array}{l}36 \pm 5 \\
40 \pm 9\end{array}$ \\
\hline
\end{tabular}

Each value represents the mean \pm s.d. of a triplicate culture in a single experiment.

Significantly different from corresponding value without TA, ${ }^{*} P<0.01 ;+P<0.05 ; \ddagger P<0.005$. 
ratio), but was enhanced by the addition of mitomycin C-treated T lymphocytes at 6 weeks after sensitization.

Based on these experiments, the in-vitro responses to testicular antigen $(100 \mu \mathrm{g}$ protein $/ \mathrm{ml})$ of $\mathrm{T}$ and $\mathrm{B}$ lymphocytes $\left(1 \times 10^{6} \mathrm{cells} / \mathrm{ml}\right)$ with or without addition of supplemental cells $(0.5 \times$ $10^{6} \mathrm{cell} / \mathrm{ml}$ ) were studied. The data presented in Table 6 compare the mean results in 4 animals at 2 weeks with those at 6 weeks after testis sensitization. Unseparated lymph node cells at both stages responded to testicular antigen, the response at 6 weeks being greater than that at 2 weeks.

Table 6. Cellular interactions among $T$ cells, $B$ cells and macrophages in testicular antigen (TA)-induced lymphocyte proliferative response in vitro

\begin{tabular}{|c|c|c|c|}
\hline \multirow{2}{*}{$\begin{array}{c}\text { Cell } \\
\text { population }\end{array}$} & \multirow{2}{*}{$\underset{(\mu \mathrm{g} \text { protein } / \mathrm{ml})}{\mathrm{TA}}$} & \multicolumn{2}{|c|}{$\left[{ }^{3} \mathrm{H}\right]$ Thymidine incorporation (c.p.m.) } \\
\hline & & 2 weeks & 6 weeks \\
\hline Unseparated cells & $\begin{array}{r}0 \\
100\end{array}$ & $\begin{array}{l}1350 \pm 443 \\
3817 \pm 719\end{array}$ & $\begin{array}{c}618 \pm 244 \\
4181 \pm 1255^{*}\end{array}$ \\
\hline $\mathrm{T}$ cells & $\begin{array}{r}0 \\
100 \\
\end{array}$ & $\begin{array}{l}35 \pm 10 \\
43 \pm 12\end{array}$ & $\begin{array}{r}36 \pm 11 \\
124 \pm 45\end{array}$ \\
\hline $\begin{array}{c}\mathrm{T}+\text { macrophages }^{\mathrm{m}} \\
1: 0.5\end{array}$ & $\begin{array}{r}0 \\
100\end{array}$ & $\begin{array}{l}195 \pm 67 \\
614 \pm 374 \dagger\end{array}$ & $\begin{array}{c}244 \pm 128 \\
1571 \pm 455 \dagger\end{array}$ \\
\hline $\begin{array}{l}\mathrm{T}+\mathrm{B} \text { cells } \mathrm{m}^{\mathrm{m}} \\
1: 0 \cdot 5 \\
\end{array}$ & $\begin{array}{r}0 \\
100 \\
\end{array}$ & $\begin{array}{c}183 \pm 80 \\
1113 \pm 385 \dagger\end{array}$ & $\begin{array}{c}247 \pm 82 \\
1544 \pm 403 \dagger\end{array}$ \\
\hline B cells & $\begin{array}{r}0 \\
100\end{array}$ & $\begin{array}{l}1933 \pm 592 \S \\
1985 \pm 670\end{array}$ & $\begin{array}{c}642 \pm 324 \\
1342 \pm 166 \ddagger\end{array}$ \\
\hline $\begin{array}{l}\mathrm{B}+\text { macrophages }^{\mathrm{m}} \\
1: 0.5\end{array}$ & $\begin{array}{r}0 \\
100\end{array}$ & $\begin{array}{l}1277 \pm 438 \\
1315 \pm 471\end{array}$ & $\begin{array}{l}360 \pm 116 \\
691 \pm 190\end{array}$ \\
\hline $\begin{array}{l}\mathrm{B}+\mathbf{T}_{\text {cells }}^{\mathrm{m}} \\
1: 0.5 \\
\end{array}$ & $\begin{array}{r}0 \\
100 \\
\end{array}$ & $\begin{array}{l}1155 \pm 258 \\
1827 \pm 265 \\
\end{array}$ & $\begin{array}{r}548 \pm 298 \\
1068 \pm 306 \\
\end{array}$ \\
\hline Macrophages $^{\mathrm{m}}$ & $\begin{array}{r}0 \\
100\end{array}$ & $\begin{array}{l}68 \pm 16 \\
54 \pm 9\end{array}$ & $\begin{array}{l}53 \pm 12 \\
53 \pm 10\end{array}$ \\
\hline B cells ${ }^{m}$ & $\begin{array}{r}0 \\
100\end{array}$ & $\begin{array}{l}90 \pm 3 \\
93 \pm 2\end{array}$ & $\begin{array}{l}83 \pm 9 \\
76 \pm 11\end{array}$ \\
\hline $\mathrm{T}$ cells $^{\mathrm{m}}$ & $\begin{array}{r}0 \\
100\end{array}$ & $\begin{array}{l}28 \pm 5 \\
26 \pm 5\end{array}$ & $\begin{array}{l}52 \pm 3 \\
50 \pm 6\end{array}$ \\
\hline
\end{tabular}

Each value is the mean \pm s.d. from 4 separate experiments. $m$, mitomycin $C$ treatment.

* Significantly different from value at 2 weeks, $P<0.02$.

+ Significantly different from value for $T$ lymphocytes alone, $P<0.05$.

$\ddagger$ Significantly different from value without TA, $P<0.02$.

$\S$ Significantly higher than value at 6 weeks, $P<0.05$.

T lymphocytes. Purified T lymphocytes alone did not respond to testicular antigen at 2 or 6 weeks. Addition of autologous mitomycin C-treated macrophages or B lymphocytes enhanced the response to testicular antigen, the B lymphocytes being the more effective at 2 weeks. Both types of cells increased spontaneous $\left[{ }^{3} \mathrm{H}\right]$ thymidine incorporation by the $\mathrm{T}$ lymphocytes.

$B$ lymphocytes. Purified B lymphocytes alone responded slightly at 6 weeks $(P<0.02)$, but spontaneous $\left[{ }^{3} \mathrm{H}\right]$ thymidine incorporation was much higher at 2 weeks than 6 weeks $(P<0 \cdot 05)$. We assumed that this baseline increment was due to a marked follicular hyperplasia of the lymph nodes occurring in the early postsensitization period. Addition of autologous mitomycin Ctreated macrophages or $\mathrm{T}$ lymphocytes had no significant effects. Throughout all these experiments, mitomycin $\mathrm{C}$ treatment almost completely blocked the capacity of $\mathrm{T}$ and $\mathrm{B}$ 
lymphocytes, and macrophages to incorporate $\left[{ }^{3} \mathrm{H}\right]$ thymidine in the absence or presence of testicular antigen.

\section{Discussion}

The experiments described in this paper indicate that the primary sensitization with testicular antigen in Freund's complete adjuvant led to a biphasic response with a low peak at Weeks 1 and 2 and a marked peak at Week 6. This pattern was also found for the delayed cutaneous reaction to testicular antigen. The early lymphocyte stimulation was coincident with the early histological changes characterized by typical orchidoepididymitis, as also described by Waksman (1959) and Tung et al. (1970), whereas the second peak was consistent with the severe aspermatogenesis observed. The subsidence of the inflammatory reaction at Week 6 , despite the predominant cellular hypersensitivity response, appears to be paradoxical. This discrepancy can be explained as due to the complete loss of sperm antigens within the affected testes, in view of our finding (unpublished) that acute inflammatory exudation in the interstitium of the testis was evoked rapidly after injection of testicular antigen or fresh spermatozoa into the atrophic testis of animals at 6 weeks after sensitization, although almost no responses occurred in similarly treated normal or control animals injected with Freund's complete adjuvant.

Muir \& Turk (1979), who reported a delayed hypersensitivity response (skin reaction, inhibition of migration of peritoneal exudate cells, lymphocyte transformation of peripheralblood leucocytes) in male guinea-pigs during 1-3 weeks after sensitization with sperm antigen, suggested that the unresponsiveness might result from a desensitization by sperm antigens released from the damaged testis. In our experimental conditions, we found only a transient depression of response rather than a marked unresponsiveness. In other immune systems, e.g. Freund's complete adjuvant sensitization (Hojo \& Hiramine, 1974), experimental allergic thyroiditis (Hiramine \& Hojo, 1975) and Nocardia infection (Hiramine, Hojo \& Yano, 1978), maximal stimulation of the proliferative response of lymph node cells to antigens was attained at 2 weeks after sensitization or infection, and was followed by a decline over the next few weeks. This decline is probably caused by regulation of the recruitment of cells which are active in cellular immunity by an intricate network of controlling mechanisms such as specialized suppressor cells and lymphokine inhibitor(s) of DNA synthesis (Waksman \& Namba, 1976).

Our data on the cellular interactions indicate that, in the absence of macrophages or B lymphocytes, purified T-cell populations taken from guinea-pigs 2 weeks and 6 weeks after sensitization failed to proliferate in response to testicular antigen, but the addition of autologous mitomycin C-treated macrophages or B lymphocytes to these $\mathrm{T}$ cell populations resulted in marked incorporation of $\left[{ }^{3} \mathrm{H}\right]$ thymidine. There is general agreement with respect to macrophage dependency of $\mathrm{T}$-cell proliferative response to mitogens or antigens (Waldron, Horn \& Rosenthal, 1973; Rosenstreich \& Oppenheim, 1976), but there has been little consideration of the possibility of B lymphocyte dependency. Romagnani et al. (1978) reported that $\mathrm{T}$ lymphocytes from human peripheral blood, which were poorly responsive to staphylococcal protein $\mathrm{A}$, became more responsive after addition of autologous mitomycin C-treated B lymphocytes. Similar results were presented by Kasahara et al. (1979) using T cell mitogens in man. We have also demonstrated the enhancing effect of $\mathrm{B}$ lymphocytes on the $\mathrm{T}$-cell response to antigen (Hojo \& Hiramine, 1978). It is presumed that B lymphocytes, probably acting as antigen-presenting and/or antigen-processing cells, can induce an antigen-specific $\mathrm{T}$-cell proliferative response comparable in magnitude to that induced by macrophages (Benacerraf, 1978; Unanue, 1978).

In this study purified B lymphocytes were able to show a small but significant proliferative response to testicular antigen at 6 weeks but not at 2 weeks. Hojo \& Hiramine $(1978,1979)$ have shown that there is a similar temporal sequence of immune responsiveness with respect to the proliferative response in vitro and blastogenic factor production by guinea-pig $\mathrm{T}$ and $\mathrm{B}$ 
lymphocytes obtained at 2 and 10-14 weeks after sensitization with Freund's complete adjuvant. A possible explanation of these observations is that the ability of lymph node cells to respond to antigens is not fully mature in the early stage, and during the advance of immunization there occurs a functional maturation and differentiation of responsible lymphocytes, more specifically of the affinity and/or the stability of the antigen receptors on these cells.

The finding that mitomycin C-treated macrophages appeared to depress rather than enhance the proliferative response of the B cells to testicular antigen is essentially similar to the observations of Lipsky \& Rosenthal (1976) and Rosenstreich \& Oppenheim (1976). The mechanism whereby macrophages exert control over the B-cell response is not fully understood. The improved response of the B cells after addition of $T$ lymphocytes is essentially similar to the report of Blomgren (1975) who found that human B lymphocytes alone were unresponsive to purified protein derivative, but were stimulated greatly by this antigen in the presence of mitomycin $\mathrm{C}$-treated $\mathrm{T}$ cells and that this cell synergy was largely explainable by soluble factors mitogenic for $B$ cells being released by the stimulated $T$ cells.

It therefore seems reasonable to conclude that the proliferative response to testicular antigen of unseparated lymph node cells at 2 weeks after testis sensitization cannot be attributed to the function of T cells or B cells acting alone, whereas the response of lymph node cells at 6 weeks is, to a certain extent, attributable to each sole function and that the proliferative response of lymph node cells during induction of experimental allergic orchitis is the expression of complex cellular interactions. It is largely the result of a collaborative event that occurs between $T$ and $B$ cells or between $T$ cells and macrophages. The available evidence favours the view, first proposed by Brown, Glynn \& Holborrow (1967) and Brown \& Glynn (1969), that cell-mediated and humoral immunity to sperm antigens are required for the full expression of experimental allergic orchitis. Antisperm antibodies appear to be involved in eliciting polymorphonuclear leucocyte-rich lesions in the rete and the epididymis and, in part, aspermatogenesis (Tung, et al., 1971; Toullet \& Voisin, 1976) but are not responsible for the cellular infiltration of seminiferous tubules, which is considered primarily as a manifestation of the cell-mediated immune reaction (Waksman, 1959; Tung et al., 1970). The dependence on T cells and independence on macrophages of the B-cell proliferation response, together with the minimal responsiveness of B cells alone to testicular antigen, strongly suggest the necessity of $\mathrm{T}$ cells for the B-cell response involving antisperm antibody formation. Since the testicular antigen is not merely a test antigen but a strong orchitogen, the data presented here may support the view that experimental allergic orchitis is exclusively a $\mathrm{T}$ lymphocyte-dependent disease.

\section{References}

Benacerraf, B. (1978) A hypothesis to relate the specificity of $T$ lymphocytes and the activity of $I$ region-specific Ir genes in macrophages and $B$ lymphocytes. J. Immun. 120, 1809-1812.

Bernard, C.C.A., Mitchell, G.F., Leydon, J. \& Bargerbos, A. (1978) Experimental autoimmune orchitis in T-cell-deficient mice. Int. Arch. Allergy 56, 256263.

Blomgren, H. (1975) Role of B cells in the expression of the PPD response of human lymphocytes in vitro. Scand. J. Immun. 4, 499-510.

Brown, P.C., Glynn, L.E. \& Holborow, E.J. (1967) The dual necessity for delayed hypersensitivity and circulating antibody in the pathogenesis of experimental allergic orchitis in guinea-pigs. Immunology 13, 307-314.
Brown, P.C. \& Glynn L.E. (1969) The early lesion of experimental allergic orchitis in guinea pigs: an immunological correlation. J. Path. 98, 277-282.

Hagopian, A., Jackson, J.J., Carlo, D.J., Limjuco, G.A. \& Eylar, E.H. (1975) Experimental allergic aspermatogenic orchitis. III. Isolation of spermatozoal glycoproteins and their role in allergic aspermatogenic orchitis. J. Immun. 115, 1731-1743.

Hiramine, C. \& Hojo, K. (1975) In vitro lymphocyte transformation in the development of experimental allergic thyroiditis. Int. Arch. Allergy 48, 750-755.

Hiramine, C., Hojo, K. \& Yano, I. (1978) Immunopathology of experimental nocardiosis in the guineapig: antigenicity and immunogenicity of Nocardia rubra extracts. Jap. J. Allergol. 27, 638-647. [In Japanese.] 
Hojo, K. \& Hiramine, C. (1974) Kinetic studies of in vitro lymphocyte responses in guinea-pigs following a single injection of complete Freund's adjuvant. Proc. Jap. Soc. Immun. 4, 144-146. [In Japanese.]

Hojo, K. \& Hiramine, C. (1978) Differences in antigen responsiveness of $\mathrm{T}$ and $\mathrm{B}$ lymphocytes and its accessory cell dependency between the early and late stages of immunization with complete Freund's adjuvant in the guinea-pig. Proc. Jap. Soc. Immun. 8, 281-282. [In Japanese.]

Hojo, K. \& Hiramine, C. (1979) Macrophage requirements of PPD-induced blastogenic factor production by $\mathbf{T}$ and $\mathbf{B}$ lymphocytes in the guinea-pig. Scand. $J$. Immun. 9, 381-386.

Kasahara, T., Kin, K., Itoh, Y., Kawai, T., Morita, M. \& Shioiri-Nakano, K. (1979) Cellular cooperation in lymphocyte activation. I. Cooperative and noncooperative responses of human $\mathrm{T}$ and $\mathrm{B}$ lymphocytes to various mitogens. Int. Arch. Allergy 58, 260-273.

Lipsky, P.E. \& Rosenthal, A.S. (1976) The induction and regulation of guinea-pig B-lymphocyte proliferation in vitro. J. Immun. 117, 1594-1602.

Lowry, O.H., Rosebrough, N.J., Farr, A.L. \& Randall, R.J. (1951) Protein measurement with the Folin phenol reagent. J. biol. Chem. 193, 265-275.

Mazzolli, A.B. (1971) Demonstration in vitro of delayed hypersensitivity in experimental allergic orchitis in guinea-pigs. J. Reprod. Fert. 26, 161-166.

Muir, V.Y. \& Turk, J.L. (1979) Immunological unresponsiveness during induction of experimental autoimmune orchitis in guinea-pigs: studies in vivo and in vitro. Immunology 36, 95-102.

Romagnani, S., Amadori, A., Giudizi, M.G., Biagiotti, R., Maggi, E. \& Ricci, M. (1978) Different mitogenic activity of soluble and insoluble staphylococcal protein A (SPA). Immunology 35, 471-478.
Rosenstreich, D.L. \& Oppenheim, J.J. (1976) The role of macrophages in the activation of $T$ and $B$ lymphocytes in vitro. In Immunobiology of the Macrophage, pp. 161-199. Ed. D. S. Nelson. Academic Press, New York.

Toullet, F. \& Voisin, G.A. (1976) Passive transfer of autoimmune aspermatogenic orchiepididymitis (AIAO) antispermatozoa sera. Influence of the type of autoantigen and of the class of antibody. Clin. exp. Immun. 26, 549-562.

Tung, K.S.K., Leong, C. \& McCarty, T. (1977) Pathogenesis of experimental allergic orchitis. III. $\mathrm{T}$ lymphocyte requirement in local adoptive transfer by peritoneal exudate cells. J. Immun. 118, 17741779.

Tung, K.S.K., Unanue, E.R. \& Dixon, E.J. (1970) The immunopathology of experimental allergic orchitis. Am. J. Path. 60, 313-328.

Tung, K.S.K., Unanue, E.R. \& Dixon, E.J. (1971) Pathogenesis of experimental allergic orchitis. II. The role of antibody. J. Immun. 106, 1463-1472.

Unanue, E.R. (1978) The regulation of lymphocyte functions by the macrophage. Immunol. Rev. 40, 227-255.

Waksman, B.H. (1959) A histopathologic study of the autoallergic testis lesion in the guinea pig. J. exp. Med. 109, 311-324.

Waksman, B.H. \& Namba, Y. (1976) On soluble mediators of immunologic regulation. Cell. Immun. 21, 161-176.

Waldron, J.A., Horn, R.G. \& Rosenthal, A.S. (1973) Antigen-induced proliferation of guinea-pig lymphocytes in vitro: obligatory role of macrophages in the recognition of antigen by immune T-lymphocytes. $J$. Immun. 111, 58-64.

Received 1 October 1979 